The Journal of Animal \& Plant Sciences, 31(1): 2021, Page: 235-245

ISSN (print): 1018-7081; ISSN (online): 2309-8694

\title{
DECONTAMINATION OF AFLATOXIN M1 IN MILK THROUGH INTEGRATION OF MICROBIAL CELLS WITH SORBITAN MONOSTEARATE, ACTIVATED CARBON AND BENTONITE
}

\author{
K. Muaz ${ }^{1}$ and M. Riaz ${ }^{*}$ \\ ${ }^{1}$ Institute of Food Science \& Nutrition, Bahauddin Zakariya University, Multan, Pakistan \\ ${ }^{*}$ Correspondence Author: Email: riaz@bzu.edu.pk
}

\begin{abstract}
Aflatoxin $\mathrm{M}_{1}\left(\mathrm{AFM}_{1}\right)$ is a highly toxic milk contaminant that poses a grave threat to human health. Among various strategies proposed for $\mathrm{AFM}_{1}$ decontamination, use of microbes have been considered to be one of the suitable techniques. However, the use of microbial cells alone had not proven to be efficient at higher $\mathrm{AFM}_{1}$ levels. Moreover, the complex between microbial cell and $\mathrm{AFM}_{1}$ had been suggested to be weaker and is dissociated soon after its exposure to washings. The objective of this study was to enhance the $\mathrm{AFM}_{1}$ binding efficiencies of bacterial cells $(\mathrm{C})$ belonging to Lactobacillus paracasei and Bacillus coagulans in the presence of activated carbon (CAC), bentonite (CBENT) and sorbitan monostearate (CSP60). The reduction of $\mathrm{AFM}_{1}$ was found to be directly proportional to the concentration of microbial cells. Heat killed and acid treated $L$. paracase $i$ successfully reduced $\mathrm{AFM}_{1}$ in milk spiked at $0.2 \mu \mathrm{g} / \mathrm{L}$ to $89 \%$ and $100 \%$ in CBENT, $84 \%$ and $90 \%$ in CAC, $59 \%$ and $47 \%$ in CSP60 and, $51.5 \%$ and $42 \%$ in C, respectively. Among treatments involving B. coagulans, acid treated CSP60 proved to be least effective showing $44.6 \%$ reduction, while CBENT for both acid and heat treated along with acid treated CAC proved to be most effective by removing $100 \% \mathrm{AFM}_{1}$. CBENT and CAC (acid and heat killed) among both bacterial strains showed the formation of most stable complex with $\mathrm{AFM}_{1}$ showing no release of detectable $\mathrm{AFM}_{1}$ after couple of phosphate buffer saline (PBS) washings. Among other treatments, CSP60 of heat killed cells formed most stable complex for both L. paracasei and B. coagulans with $19 \%$ and $22 \%$ release of initially bound $\mathrm{AFM}_{1}$, respectively. The results showed that the combination of microbial cells with activated carbon and bentonite may be used as an efficient and effective strategy to mitigate the problem of $\mathrm{AFM}_{1}$ in milk.
\end{abstract}

Keywords: Aflatoxin $\mathrm{M}_{1}$; decontamination; lactic acid bacteria; activated carbon; bentonite

https://doi.org/10.36899/JAPS.2021.1.0210

Published online August 26, 2020

\section{INTRODUCTION}

Aflatoxins (AFs) are secondary metabolites of a few Aspergilli including Aspergillus flavus, Aspergillus parasiticus, Aspergillus nomius, Aspergillus bombycis and Aspergillus pseudotamarii (Cotty and Cardwell, 1999; Kurtzman et al., 1987; Mishra and Das, 2003; Peterson et al., 2001). Among all the AFs, aflatoxin $\mathrm{B}_{1}$ $\left(\mathrm{AFB}_{1}\right)$ is known to be the most potent natural carcinogen to humans. Mammals fed on diet contaminated with $\mathrm{AFB}_{1}$, tend to produce aflatoxin $\mathrm{M}_{1}\left(\mathrm{AFM}_{1}\right)$ through hydroxylation of tertiary carbon atom present in the difuran rings metabolized by cytochrome P450 enzyme system in the liver (Fallah et al., 2011). Although, $\mathrm{AFM}_{1}$ has been shown to be 10 times less toxic as compared to $\mathrm{AFB}_{1}$, its harmful effects are still a grave threat to immunologically vulnerable age groups particularly children and elderly due to consumption of milk in higher amounts (Maqbool et al., 2009; Munir et al., 1989). $\mathrm{AFM}_{1}$ is known to possess carcinogenic, teratogenic, cytotoxic and genotoxic character (Neal et al., 1998; Shibahara et al., 1995). To cope with severe threats from presence of $\mathrm{AFM}_{1}$ in milk and milk products, many countries have established regulations regarding its maximum permissible limits. The most widely accepted maximum limit for $\mathrm{AFM}_{1}$ in milk is $0.05 \mu \mathrm{g} / \mathrm{l}$ set by European Union and $0.5 \mu \mathrm{g} / \mathrm{l}$ set by Codex Alimentarius as well as by FDA (Fallah, 2010).

The presence of $\mathrm{AFM}_{1}$ in milk has been reported all round the world. However, the developing countries are especially at stake due to lack of awareness, poor monitoring system and insufficient regulatory infrastructure (Ismail et al., 2016). Moreover, absence of suitable practices for production and improper storage of animal feed augment the threat of these toxins. The paramount technique to avoid presence of $\mathrm{AFM}_{1}$ in milk is to prevent cattle from consumption of feed contaminated with $\mathrm{AFB}_{1}$, adopting good agricultural and good animal feeding practices. But, due to lack of suitable facilities, it may practically be impossible to prevent the contamination of feed with $\mathrm{AFB}_{1}$ and subsequently $\mathrm{AFM}_{1}$ in milk. Hence, there is a need to develop such novel techniques which are safe and cost effective to reduce levels of $\mathrm{AFM}_{1}$ in milk. Amongst different strategies for decontamination of $\mathrm{AFM}_{1}$, use of 
probiotics and lactic acid bacteria (LAB) has been proposed to be effective (Bovo et al., 2013; Peltonen et al., 2000). Various levels of decontamination of $\mathrm{AFM}_{1}$ from milk ranging up to $100 \%$ have been achieved using microbial cells (Corassin et al., 2013). However, the complex formed between microbial cell and AFM1, being reversible, disassociates releasing major amount of $\mathrm{AFM}_{1}$ back into the medium during washing (Ismail et al., 2017; Serrano-Niño et al., 2013). The exact mechanism of $\mathrm{AFM}_{1}$ binding with microbial cells is still not clear, however a few studies have proposed the involvement of hydrophobic interactions of $\mathrm{AFM}_{1}$ with various components of cell walls of gram positive bacteria (Haskard et al., 2000; Lahtinen et al., 2004). Furthermore, the complex may not be stable due to the fact that aflatoxin can be retained in water due to hydrophilic interactions (Pierides et al., 2000). Nevertheless, there is a need for further studies to understand the exact mechanism and to identify certain compounds that can enhance the stability and efficiency of microbes-AFM ${ }_{1}$. In this regard, certain surfactants may be helpful by forming a bridge between the cell wall and $\mathrm{AFM}_{1}$ molecules. Sorbitan monostearate (Span 60) is a common hydrophobic surfactant used in food processing industries.

Moreover, there have been several studies aiming decontamination of aflatoxins using activated carbon and clay minerals such as bentonite among which a limited number have been focused upon $\mathrm{AFM}_{1}$ (Carraro et al., 2014; Di Natale et al., 2009). Activated carbon is a processed carbon having low volume pores which increases its surface area for adsorption, while clay minerals are small particles existing on Earth's surface consisting mainly of silica, alumina or magnesia. Activated carbon and bentonite have also not been reported to pose any potential threat even through direct contact with food stuff (Wang et al., 2005). The use of bentonite in food is mentioned in USA regulations (FDA, 2018) listing bentonite as GRAS (generally recognized as safe) ingredient that can be used human food. But the use of these adsorbents in higher concentrations for treatment of milk to decontaminate $\mathrm{AFM}_{1}$ can affect the milk quality (Carraro et al., 2014). Although the use of microbial cells and these adsorbents have been carried out individually to reduce $\mathrm{AFM}_{1}$ levels in milk, but the combination of these agents have not been tested. Since these agents are already being used in food processing industries, hence their application in milk industry for decontamination of $\mathrm{AFM}_{1}$ is justified.

Due to the capabilities of probiotics to reduce $\mathrm{AFM}_{1}$ in milk, two of the probiotic strains which previously had not been tested for their $\mathrm{AFM}_{1}$ binding abilities, namely Lactobacillus paracasei and Bacillus coagulans, were selected for this study. Both the strains exhibit probiotic properties and have been regarded safe for long term human exposure (Endres et al., 2009; Jia et al., 2011; Phillips et al., 2006). The objectives of this study was to enhance the $\mathrm{AFM}_{1}$ binding efficiency of selected bacterial strains in the presence of sorbitan monostearate, activated carbon and bentonite. Moreover, the stability of microbial-AFM $\mathrm{A}_{1}$ complex among all the treatments was analyzed through phosphate buffer saline (PBS) solution washings.

\section{MATERIALS AND METHODS}

The experiment involved the assessment for impact of heat and acid treatment on different concentrations of bacterial cells $\left(10^{7}, 10^{8}\right.$ and $\left.10^{9} \mathrm{cfu} / \mathrm{ml}\right)$ and their combination with different agents (Span 60, activated carbon and bentonite) on the reduction of $\mathrm{AFM}_{1}$ in milk spiked at three different levels of $\mathrm{AFM}_{1}(0.05,0.1$ and $0.2 \mu \mathrm{g} / \mathrm{L}$ ). Two bacterial strains were studied independently during the analysis. The extent of initially bound $\mathrm{AFM}_{1}$ released after two PBS washings was also assessed during the study.

Materials: Two bacterial strains namely Lactobacillus paracasei (L. paracasei) CECT 4022 and Bacillus coagulans (B. coagulans) CECT 12 were obtained in lyophilized form directly from Spanish Type Culture Collection. $\mathrm{AFM}_{1}$ standard solution of $500 \mu \mathrm{g} / \mathrm{L}$ was obtained from Romer Labs Diagnostic GmbH (Art \# 002030). Activated carbon (SKU 18001), bentonite (SKU 285234) and sorbitan monostearate (SKU S7010) were purchased from Sigma Aldrich, USA. The ELISA kits used for quantification of $\mathrm{AFM}_{1}$ in the samples were obtained from Romer Labs Inc. (AgraQuant ${ }^{\circledR}$ Aflatoxin M1 Sensitive COKAQ7100).

Preparation of Bacterial Culture: L. paracasei CECT 4022 and B. coagulans CECT 12 were activated in MRS Broth and Nutrient Broth, respectively at $30^{\circ} \mathrm{C}$ for 24 hours. Subsequently, both of the cultures were streaked on their respective solid media and incubated for 24 hours at $30^{\circ} \mathrm{C}$. Afterwards, isolated colonies of both the strains were used for estimation of bacterial concentration through turbidimetric method as described by Bovo et al. (2013) and Ismail et al. (2017). The growth curves were constructed by correlation of colony count through spread plate method and corresponding absorbance observed at $600 \mathrm{~nm}$ using spectrophotometer (UV 3000 Vis Spectrophotometer, ORI Germany). The volumes of culture broth containing $10^{7}, 10^{8}$ and $10^{9} \mathrm{cfu}$ of $L$. paracasei CECT 4022 and B. coagulans CECT 12 were centrifuged at $3000 \times g$ for 15 minutes to obtain pellets of respective cells.

Preparation of Heat and Acid Killed Bacterial Cells: The heat killed microbial cells were obtained after resuspending the $L$. paracasei CECT 4022 and $B$. coagulans CECT 12 pellets separately in PBS and placing in water bath at $90^{\circ} \mathrm{C}$ for 1 hour. Acid treated 
bacteria were prepared by re-suspending the L. paracase CECT 4022 and B. coagulans CECT 12 cells in $2 \mathrm{M} \mathrm{HCl}$ followed by incubation at $37^{\circ} \mathrm{C}$ for 1 hour. Acid treated bacterial cells were washed twice with PBS to remove any residues of acid in order to prevent any chemical denaturation of $\mathrm{AFM}_{1}$. Both acid and heat killed treatments were centrifuged at $3000 \times \mathrm{g}$ for 15 minutes to obtain pallets of bacterial cells (El-Nezami et al., 1998b; Ismail et al., 2017).

Preparation of Spiked Milk Samples: Raw cow milk was purchased from the local farmer and pasteurized at $63^{\circ} \mathrm{C}$ for 30 minutes to prevent any deteriorative changes from microbial activity. Afterwards, the fat was removed through centrifugation at $3000 \times g$ for 5 minutes in order to prevent any matrix interferences in further analysis. The presence of $\mathrm{AFM}_{1}$ in milk below detection limits was ensured. The final concentrations of $0.05,0.1$ and 0.2 $\mu \mathrm{g} / \mathrm{L}$ of $\mathrm{AFM}_{1}$ spiked milk samples were prepared by adding $10 \mu \mathrm{l}, 20 \mu \mathrm{l}$ and $40 \mu \mathrm{l}$ of $\mathrm{AFM}_{1}$ standard separately in $100 \mathrm{ml}$ skim milk for further investigations.

Decontamination of AFM through Bacterial Cells and their Combination with Activated Carbon, Bentonite and Sorbitan Monostearate: The nonviable bacterial cells $(\mathrm{C})$, both heat killed and acid treated, having $10^{7}, 10^{8}$ and $10^{9} \mathrm{cfu}$ were separately re-suspended in $1 \mathrm{ml}$ of spiked milk samples. For treatments combined with activated carbon (CAC) or bentonite (CBENT), the suspension of bacterial cells in milk was added with activated carbon and bentonite (2\% each). Span 60 treatment (CSP60) was prepared by suspending the bacterial cells in $1 \mathrm{ml}$ solution of $0.2 \%$ span 60 followed by centrifugation at $3000 \times g$ for 15 minutes and resuspending in $1 \mathrm{ml}$ of $\mathrm{AFM}_{1}$ spiked milk samples. All of the treatments were incubated at $37^{\circ} \mathrm{C}$ for 1 hour followed by centrifugation at $3000 \times g$ for 15 minutes to assess the decontamination of $\mathrm{AFM}_{1}$.

Stability Testing of Microbial Cell-AFM Complex: The stability of microbial cell-AFM ${ }_{1}$ complex for all the treatments (C, CAC, CBENT \& CSP60) was analyzed by washing the pellets twice with PBS as described by Ismail et al. (2017). The pellets were re-suspended in PBS and mixed thoroughly using vortex mixer for 20 seconds. The cells were centrifuged at $3000 \times g$ for $15 \mathrm{~min}$ to collect the supernatant for quantification of released $\mathrm{AFM}_{1}$ after each washing.

Quantification of AFM $_{1}$ : Supernatants $(0.4 \mathrm{ml})$ from centrifuged samples of C, CAC, CBENT \& CSP60 were mixed separately with $0.1 \mathrm{ml}$ of methanol (Sigma Aldrich) to quantify $\mathrm{AFM}_{1}$ through ELISA. The mixture (100 $\mu \mathrm{l}$ each) was added to $200 \mu \mathrm{l}$ of conjugate solution in dilution wells and mixed thoroughly. Afterwards, 100 $\mu \mathrm{l}$ from each dilution well was transferred to respective antibody coated micro well followed by incubation at room temperature for 1 hour. The microwells were then drained off, washed with washing buffer and dried by tapping the microwells on several layers of adsorbent paper at flat surface followed by addition of $100 \mu \mathrm{l}$ substrate to each microwell and incubation for 20 minutes at room temperature in dark. Stop solution $(100 \mu \mathrm{l})$ was added to each microwell to quench the reaction. The absorbance was measured at $450 \mathrm{~nm}$ by placing the micro well plate in ELISA reader (Bio-Tek ELx800, Indonesia) as recommended by the manufacturer.

The absorption intensity was observed to be inversely proportional to the $\mathrm{AFM}_{1}$ concentration. The $\log -\operatorname{logit} \mathrm{AFM}_{1}$ sheet supplied with the kit was used to generate a standard curve and calculate the concentration of AFM1 in the samples. Furthermore, the ELISA method was validated by analyzing the recovery percentages of $\mathrm{AFM}_{1}$ in milk spiked at $0.025,0.05,0.1$ and $0.2 \mu \mathrm{g} / \mathrm{L}$.

Statistical Analysis: All the treatments were analyzed in triplicates and the results were expressed in mean $\pm \mathrm{SD}$. The statistical analysis of data was performed using three way ANOVA and LSD using Statistix 8.1 to analyze statistical significant differences among treatments within milk samples spiked with same $\mathrm{AFM}_{1}$ levels. The probability level of $<0.05$ was considered to be statistically significant.

\section{RESULTS}

ELISA Method Validation: The standard curve is shown in Figure. 1. The efficiency of ELISA method is presented in Table 1. The recovery of spiked milk samples were found in the ranges of $94.7 \%$ to $97 \%$. The limit of detection provided by the manufacturer for ELISA kits used in current study was $0.018 \mu \mathrm{g} / \mathrm{L}$.

Decontamination of AFM $_{1}$ through Lactobacillus paracasei Combined with Activated Carbon, Bentonite and Sorbitan Monostearate: Significant differences were observed among the treatments of spiked milk with different levels of $\mathrm{AFM}_{1}$ having various concentrations of microbial cells (Table. 2). Among $0.05 \mu \mathrm{g} / \mathrm{L} \mathrm{AFM}_{1}$ spiked milk samples, residual levels below detection limits revealed that maximum reduction of the toxin was exhibited by CAC and CBENT for both acid treated and heat killed samples. The minimum $\mathrm{AFM}_{1}$ reduction was exhibited by the acid treated $\mathrm{C}$ with $27 \%, 42 \%$ and $60 \%$ $\mathrm{AFM}_{1}$ removal against $10^{7}, 10^{8}$ and $10^{9} \mathrm{cfu} / \mathrm{ml}$, respectively. Higher amounts of $\mathrm{AFM}_{1}$ were removed from spiked milk by heat killed treatments C and CSP60 as compared to their corresponding acid treatments. The amount of $\mathrm{AFM}_{1}$ reduced through heat treated $\mathrm{C}$ was $32 \%$ and $55 \%$ in correspondence to $10^{7}$ and $10^{8} \mathrm{cfu} / \mathrm{ml}$, respectively. Moreover, reduction of $42 \%$ was observed against $10^{7} \mathrm{cfu} / \mathrm{ml}$ and no residual $\mathrm{AFM}_{1}$ was detected in treatment with $10^{8} \mathrm{cfu} / \mathrm{ml}$ heat killed cells treated with CSP60. Furthermore, all the treatments involving $10^{9}$ 
cfu/ml microbial cells reduced the $\mathrm{AFM}_{1}$ below detection limits except for acid treated $\mathrm{C}$.

Among milk samples spiked with $0.1 \mu \mathrm{g} / \mathrm{L}$ $\mathrm{AFM}_{1}$, no detectable amounts of $\mathrm{AFM}_{1}$ were observed in CAC and CBENT for both acid treated and heat killed treatments. The reduction rate of $\mathrm{AFM}_{1}$ was observed to be less for acid treated than heat treated cells (C treatment). Next to CAC and CBENT, $\mathrm{AFM}_{1}$ was observed to be reduced maximum in heat killed CSP60 samples in order of $10^{7}<10^{8}<10^{9} \mathrm{cfu} / \mathrm{ml}$ showing $40 \%$, $64 \%$ and $76 \%$ reduction, respectively. Minimum reduction among all treatments was observed in acid treated cells (C treatment) showing decrease of $25 \%$, $47 \%$ and $62 \%$ in $\mathrm{AFM}_{1}$ against $10^{7}, 10^{8}$ and $10^{9} \mathrm{cfu} / \mathrm{ml}$, respectively.

Similar trend was observed for milk samples spiked with $0.2 \mu \mathrm{g} / \mathrm{L} \mathrm{AFM}_{1}$. The heat killed treatments except for CAC and CBENT reduced more $\mathrm{AFM}_{1}$ as compared to acid treated treatments. The levels of $\mathrm{AFM}_{1}$ reduced by CAC with $10^{7}, 10^{8}$ and $10^{9} \mathrm{cfu} / \mathrm{ml}$ were $81 \%$, $82 \%$ and $82 \%$ for heat killed treatments while $84 \%, 88 \%$ and $90 \%$ for acid treated treatments, respectively. Higher reduction was observed for $10^{9} \mathrm{cfu} / \mathrm{ml}$ cells between all the treatments spiked with $0.2 \mu \mathrm{g} / \mathrm{L} \quad \mathrm{AFM}_{1}$, amongst which acid treated CBENT and $\mathrm{C}$ were found to bind the highest $(<\mathrm{LOD})$ and lowest $(42 \%)$ amounts of $\mathrm{AFM}_{1}$, respectively.

Decontamination of AFM through Bacillus coagulans combined with Activated Carbon, Bentonite and Sorbitan Monostearate: The decontamination of $\mathrm{AFM}_{1}$ through B. coagulans combined with activated carbon, bentonite and sorbitan monostearate in milk samples spiked with $0.05 \mu \mathrm{g} / \mathrm{L} \mathrm{AFM}_{1}$ was observed to be highest $(<\mathrm{LOD})$ by CAC and CBENT among both heat killed and acid treated bacterial cells (Table. 3). Among all the treatments spiked with $0.05 \mu \mathrm{g} / \mathrm{L} \quad \mathrm{AFM}_{1}$, minimum reduction was observed for acid treated CSP60 with removal of $28 \%, 44 \%$ and $60 \% \mathrm{AFM}_{1}$ against $10^{7}, 10^{8}$ and $10^{9} \mathrm{cfu} / \mathrm{ml}$ of B. coagulans, respectively. In contrast, the acid treated $\mathrm{C}$ treatment reduced $\mathrm{AFM}_{1}$ levels by $50 \%$ and $62 \%$ through $10^{7}$ and $10^{8} \mathrm{cfu} / \mathrm{ml}$, respectively, while no detectable amounts of $\mathrm{AFM}_{1}$ were observed in $\mathrm{C}$ treatment with $10^{9} \mathrm{cfu} / \mathrm{ml}$ bacterial cells. The reduction achieved through heat killed treatment $\mathrm{C}$ was observed to be $38 \%$ and $48 \%$ against $10^{7}$ and $10^{8} \mathrm{cfu} / \mathrm{ml}$. The heat treated CSP60 reduced $52 \% \mathrm{AFM}_{1}$ against $10^{7} \mathrm{cfu} / \mathrm{ml}$. No detectable amounts were observed for heat treated $\mathrm{C}$ involving $10^{9} \mathrm{cfu} / \mathrm{ml}$ and CSP60 involving $10^{9}$ and $10^{8}$ $\mathrm{cfu} / \mathrm{ml}$ B. coagulans.

The treatments CAC and CBENT for both acid treated and heat killed cells decreased the residual $\mathrm{AFM}_{1}$ levels to below detection limits $(<\mathrm{LOD})$ at all microbial concentrations in milk samples spiked with $0.1 \mu \mathrm{g} / \mathrm{L}$ $\mathrm{AFM}_{1}$. Minimum reduction was observed by the acid treated CSP60 treatment exhibiting 31\%, 46\% and $64 \%$ for $10^{7}, 10^{8}$ and $10^{9} \mathrm{cfu} / \mathrm{ml}$ bacterial cells, respectively. The treatment $\mathrm{C}$ for acid treated cells was found to be most efficient in $\mathrm{AFM}_{1}$ removal after CAC and CBENT in milk samples added with $0.1 \mu \mathrm{g} / \mathrm{L} \mathrm{AFM}_{1}$ showing $48.37 \%, 63.3 \%$ and $78.56 \%$ reduction through $10^{7}, 10^{8}$ and $10^{9} \mathrm{cfu} / \mathrm{ml}$, respectively.

For samples spiked with $0.2 \mu \mathrm{g} / \mathrm{L} \quad \mathrm{AFM}_{1}$, maximum reduction was observed for CBENT among both heat killed and acid treated, while for CAC in only acid treated samples with residual $\mathrm{AFM}_{1}$ levels $<$ LOD against $10^{9} \mathrm{cfu} / \mathrm{ml}$ bacterial cells. Higher reduction was observed for heat killed CBENT (85\% and $89 \%$ ) as compared to acid treated CAC and CBENT $(83 \%$ and $87 \%$ for both treatments) against $10^{7}$ and $10^{8} \mathrm{cfu} / \mathrm{ml}$, respectively. Minimum reduction of $\mathrm{AFM}_{1}$ among samples spiked with $0.2 \mu \mathrm{g} / \mathrm{L}$ was observed in acid treated CSP60 with $14 \%, 22 \%$ and $45 \%$ removal against $10^{7}, 10^{8}$ and $10^{9} \mathrm{cfu} / \mathrm{ml}$ bacterial cells, respectively. Among remaining treatments, highest reductions were observed through heat killed CSP60 treatment showing $25 \%, 47 \%$ and $59 \%$ removal of $\mathrm{AFM}_{1}$ for $10^{7}, 10^{8}$ and $10^{9} \mathrm{cfu} / \mathrm{ml}$ cells, respectively. Furthermore, acid treated C showed higher efficiency for $\mathrm{AFM}_{1}$ removal $(24 \%, 33 \%$ and $57 \%)$ as compared to heat treated $(21 \%, 29 \%$ and $53 \%)$ B. coagulans at $10^{7}, 10^{8}$ and $10^{9} \mathrm{cfu} / \mathrm{ml}$, respectively.

Stability Testing of Microbial Cell-AFM Complex: The treatments CAC and CBENT for both $L$. paracasei and $B$. coagulans did not release any $\mathrm{AFM}_{1}$ in detectable amounts showing a stable complex formation. Furthermore, no detectable amounts of $\mathrm{AFM}_{1}$ were released after 2 washings with PBS solution for any treatment at $0.05 \mu \mathrm{g} / \mathrm{L}$ and $0.1 \mu \mathrm{g} / \mathrm{L}$. While at $0.2 \mu \mathrm{g} / \mathrm{L}$, detectable amounts were released by both heat killed and acid treated microbes at $10^{9} \mathrm{cfu} / \mathrm{ml}$ in treatments $\mathrm{C}$ and CSP60. For L. paracasei, among the treatments spiked with $0.2 \mu \mathrm{g} / \mathrm{L} \mathrm{AFM}_{1}, \mathrm{C}$ and CSP60 having $10^{9} \mathrm{cfu} / \mathrm{ml}$ released detectable amounts of $\mathrm{AFM}_{1}$ during the washing treatments amounting up to $53 \%$ and $19 \%$ in heat killed cells while $30 \%$ and $61 \%$ for acid treated cells after two washings, respectively (Figure. 2. a).

For B. coagulans, lower amounts were released by heat killed CSP 60 with $22 \%$ release of initially bound $\mathrm{AFM}_{1}$ during first washing and no release of detectable amounts after second washing. While, maximum amounts were released by acid treated CSP60 releasing 33\% and $22 \%$ of initially bound $\mathrm{AFM}_{1}$ during first and second washing, respectively (Figure. 2. b). 
Table 1. ELISA Method Efficiency and Validation for AFM1.

\begin{tabular}{cccc}
\hline $\begin{array}{c}\text { Spiked AFM1 in milk } \\
(\boldsymbol{\mu g} / \mathbf{L})\end{array}$ & $\begin{array}{c}\text { AFM1 Detected } \\
(\boldsymbol{\mu g} / \mathbf{L})\end{array}$ & Recovery $\%$ & Variation Coefficient \\
\hline 0.025 & 0.0237 & 94.7 & 2.44 \\
0.050 & 0.0480 & 96.0 & 2.08 \\
0.100 & 0.0967 & 96.7 & 1.58 \\
0.200 & 0.1940 & 97.0 & 1.55 \\
\hline
\end{tabular}

Table. 2 Residual levels of $\mathbf{A F M}_{1}(\mu \mathrm{g} / \mathrm{L})$ after decontamination of milk spiked at different concentrations of AFM 1 with heat killed and acid treated $L$. paracasei cells in combination with sorbitan monostearate, activated carbon and bentonite.

\begin{tabular}{|c|c|c|c|c|c|}
\hline \multirow{2}{*}{$\begin{array}{c}\text { Microbial } \\
\text { Cells } \\
\text { (Cfu/ml) }\end{array}$} & \multirow{2}{*}{$\begin{array}{l}\text { Heat/Acid } \\
\text { Treatment }\end{array}$} & \multirow[b]{2}{*}{ Treatment } & \multicolumn{3}{|c|}{ Residual AFM ${ }_{1}$ in $\mu \mathrm{g} / \mathrm{L}$ (Reduction \%) } \\
\hline & & & 0.05 & 0.1 & 0.2 \\
\hline \multirow{8}{*}{$10^{7}$} & \multirow{4}{*}{ Heat killed } & $\mathrm{C}^{\mathrm{a}}$ & $0.0339 \pm 0.0015^{\mathrm{B}}(32.2)$ & $0.0662 \pm 0.0024^{\mathrm{B}}(33.8)$ & $0.1632 \pm 0.0026^{\mathrm{B}}(18.4)$ \\
\hline & & $\mathrm{CSP} 60^{\mathrm{b}}$ & $0.0289 \pm 0.0018^{\mathrm{D}}(42.2)$ & $0.0596 \pm 0.0006^{\mathrm{C}}(40.4)$ & $0.1501 \pm 0.0011^{\mathrm{D}}(25)$ \\
\hline & & $\mathrm{CAC}^{\mathrm{c}}$ & $<\mathrm{LOD}^{\mathrm{G}}$ & $<\mathrm{LOD}^{\mathrm{K}}$ & $0.0381 \pm 0.0012^{\mathrm{K}}(81)$ \\
\hline & & CBENT $^{d}$ & $<\mathrm{LOD}^{\mathrm{G}}$ & $<\mathrm{LOD}^{\mathrm{K}}$ & $0.0279 \pm 0.0013^{\mathrm{N}}(86.05)$ \\
\hline & \multirow{4}{*}{$\begin{array}{l}\text { Acid } \\
\text { treated }\end{array}$} & $\mathrm{C}$ & $0.0366 \pm 0.0012^{\mathrm{A}}(26.8)$ & $0.0747 \pm 0.0013^{\mathrm{A}}(25.3)$ & $0.1734 \pm 0.0017^{\mathrm{A}}(13.3)$ \\
\hline & & CSP60 & $0.0306 \pm 0.0014^{\mathrm{C}}(38.8)$ & $0.0662 \pm 0.0007^{\mathrm{B}}(33.8)$ & $0.1561 \pm 0.0011^{\mathrm{C}}(21.95)$ \\
\hline & & CAC & $<\mathrm{LOD}^{\mathrm{G}}$ & $<\mathrm{LOD}^{\mathrm{K}}$ & $0.0314 \pm 0.0011^{\mathrm{M}}(84.3)$ \\
\hline & & CBENT & $<\mathrm{LOD}^{\mathrm{G}}$ & $<\mathrm{LOD}^{\mathrm{K}}$ & $0.0243 \pm 0.0012^{\mathrm{O}}(87.85)$ \\
\hline \multirow{8}{*}{$10^{8}$} & \multirow{4}{*}{ Heat killed } & $\mathrm{C}$ & $0.0227 \pm 0.0015^{\mathrm{E}}(54.6)$ & $0.0396 \pm 0.0024^{\mathrm{F}}(60.4)$ & $0.1302 \pm 0.0029^{\mathrm{E}}(34.9)$ \\
\hline & & CSP60 & $<\mathrm{LOD}^{\mathrm{G}}$ & $0.0362 \pm 0.0007^{\mathrm{G}}(63.8)$ & $0.1092 \pm 0.0015^{\mathrm{G}}(45.4)$ \\
\hline & & CAC & $<\mathrm{LOD}^{\mathrm{G}}$ & $<\mathrm{LOD}^{\mathrm{K}}$ & $0.0354 \pm 0.0006^{\mathrm{L}}(82.3)$ \\
\hline & & CBENT & $<\mathrm{LOD}^{\mathrm{G}}$ & $<\mathrm{LOD}^{\mathrm{K}}$ & $0.024 \pm 0.0013^{\circ}(88)$ \\
\hline & \multirow{4}{*}{$\begin{array}{l}\text { Acid } \\
\text { treated }\end{array}$} & $\mathrm{C}$ & $0.0291 \pm 0.0013^{\mathrm{D}}(41.8)$ & $0.0527 \pm 0.0025^{\mathrm{D}}(47.3)$ & $0.1562 \pm 0.0013^{\mathrm{C}}(21.9)$ \\
\hline & & CSP60 & $0.0239 \pm 0.0003^{\mathrm{E}}(52.2)$ & $0.0421 \pm 0.001^{\mathrm{E}}(57.9)$ & $0.1308 \pm 0.0013^{\mathrm{E}}(34.6)$ \\
\hline & & CAC & $<\mathrm{LOD}^{\mathrm{G}}$ & $<\mathrm{LOD}^{\mathrm{K}}$ & $0.0236 \pm 0.0008^{\mathrm{OP}}(88.2)$ \\
\hline & & CBENT & $<\mathrm{LOD}^{\mathrm{G}}$ & $<\mathrm{LOD}^{\mathrm{K}}$ & $0.0214 \pm 0.0007^{\mathrm{PQ}}(89.3)$ \\
\hline \multirow{8}{*}{$10^{9}$} & \multirow{4}{*}{ Heat killed } & $\mathrm{C}$ & $<\mathrm{LOD}^{\mathrm{G}}$ & $0.0276 \pm 0.0027^{\mathrm{I}}(72.4)$ & $0.0970 \pm 0.0019^{\mathrm{I}}(51.5)$ \\
\hline & & CSP60 & $<\mathrm{LOD}^{\mathrm{G}}$ & $0.0238 \pm 0.0019^{\mathrm{J}}(76.2)$ & $0.0821 \pm 0.0016^{\mathrm{J}}(58.95)$ \\
\hline & & CAC & $<\mathrm{LOD}^{\mathrm{G}}$ & $<\mathrm{LOD}^{\mathrm{K}}$ & $0.0318 \pm 0.0016^{\mathrm{M}}(84.1)$ \\
\hline & & CBENT & $<\mathrm{LOD}^{\mathrm{G}}$ & $<\mathrm{LOD}^{\mathrm{K}}$ & $0.0218 \pm 0.0007^{\mathrm{OPQ}}(89.1)$ \\
\hline & \multirow{4}{*}{$\begin{array}{l}\text { Acid } \\
\text { treated }\end{array}$} & $\mathrm{C}$ & $0.0198 \pm 0.0011^{\mathrm{F}}(60.4)$ & $0.0383 \pm 0.001^{\mathrm{F}}(61.7)$ & $0.1159 \pm 0.0024^{\mathrm{F}}(42.05)$ \\
\hline & & CSP60 & $<\mathrm{LOD}^{\mathrm{G}}$ & $0.0311 \pm 0.0016^{\mathrm{H}}(68.9)$ & $0.1060 \pm 0.0019^{\mathrm{H}}(47)$ \\
\hline & & CAC & $<\mathrm{LOD}^{\mathrm{G}}$ & $<\mathrm{LOD}^{\mathrm{K}}$ & $0.0200 \pm 0.0017^{\mathrm{Q}}(90)$ \\
\hline & & CBENT & $<\mathrm{LOD}^{\mathrm{G}}$ & $<\mathrm{LOD}^{\mathrm{K}}$ & $<\mathrm{LOD}^{\mathrm{R}}$ \\
\hline
\end{tabular}

${ }^{\mathrm{a}} \mathrm{C}$ : Cells only, $\quad{ }^{\mathrm{b}} \mathrm{CSP} 60$ : Cells treated with sorbitan monostearate (Span 60$),{ }^{\mathrm{c}} \mathrm{CAC}$ : Cells in combination with activated carbon ${ }^{\mathrm{d}}$ CBENT: Cells in combination with bentonite

Different capital letters within same column show significant difference $(\mathrm{p}<0.05)$

Table. 3 Residual levels of AFM $_{1}(\mu \mathrm{g} / \mathrm{L})$ after decontamination of milk spiked at different concentrations of AFM1 with heat killed and acid treated $B$. coagulans cells in combination with Sorbitan Monostearate, Activated Carbon and Bentonite.

\begin{tabular}{|c|c|c|c|c|c|}
\hline \multirow{2}{*}{$\begin{array}{c}\text { Microbial } \\
\text { Cells } \\
(\text { Cfu } / \mathrm{ml})\end{array}$} & \multirow{2}{*}{$\begin{array}{l}\text { Heat/Acid } \\
\text { Treatment }\end{array}$} & \multirow[b]{2}{*}{ Treatment } & \multicolumn{3}{|c|}{ Residual AFM1 in $\mu \mathrm{g} / \mathrm{L}($ Reduction \%) } \\
\hline & & & 0.05 & 0.1 & 0.2 \\
\hline \multirow{5}{*}{$10^{7}$} & \multirow{4}{*}{ Heat killed } & $\mathrm{C}^{\mathrm{a}}$ & $0.0310 \pm 0.0017^{\mathrm{B}}(38)$ & $0.0592 \pm 0.0026^{\mathrm{B}}(40.8)$ & $0.1582 \pm 0.0030^{\mathrm{B}}(20.9)$ \\
\hline & & $\mathrm{CSP} 60^{\mathrm{b}}$ & $0.0238 \pm 0.0008^{\mathrm{E}}(52.4)$ & $0.0539 \pm 0.0021^{\mathrm{C}}(46.1)$ & $0.1500 \pm 0.0015^{\mathrm{C}}(25)$ \\
\hline & & $\mathrm{CAC}^{\mathrm{c}}$ & $<\mathrm{LOD}^{\mathrm{G}}$ & $<\mathrm{LOD}^{\mathrm{J}}$ & $0.0426 \pm 0.0008^{\mathrm{K}}(78.7)$ \\
\hline & & CBENT $^{\mathrm{d}}$ & $<\mathrm{LOD}^{\mathrm{G}}$ & $<\mathrm{LOD}^{\mathrm{J}}$ & $0.0298 \pm 0.0019^{\mathrm{N}}(85.1)$ \\
\hline & Acid & $\mathrm{C}$ & $0.0248 \pm 0.0012^{\mathrm{DE}}(50.4)$ & $0.0516 \pm 0.0015^{\mathrm{D}}(48.4)$ & $0.1527 \pm 0.0018^{\mathrm{C}}(23.7)$ \\
\hline
\end{tabular}




\begin{tabular}{|c|c|c|c|c|c|}
\hline & treated & $\begin{array}{l}\text { CSP60 } \\
\text { CAC } \\
\text { CBENT }\end{array}$ & $\begin{array}{c}0.0358 \pm 0.0015^{\mathrm{A}}(28.4) \\
<\mathrm{LOD}^{\mathrm{G}} \\
<\mathrm{LOD}^{\mathrm{G}}\end{array}$ & $\begin{array}{c}0.0686 \pm 0.0018^{\mathrm{A}}(31.4) \\
<\mathrm{LOD}^{\mathrm{J}} \\
<\mathrm{LOD}^{\mathrm{J}}\end{array}$ & $\begin{array}{c}0.1711 \pm 0.0022^{\mathrm{A}}(14.5) \\
0.0327 \pm 0.0016^{\mathrm{LM}}(83.7) \\
0.0343 \pm 0.0020^{\mathrm{L}}(82.9)\end{array}$ \\
\hline \multirow{8}{*}{$10^{8}$} & \multirow{4}{*}{ Heat killed } & $\mathrm{C}$ & $0.0260 \pm 0.0018^{\mathrm{D}}(48)$ & $0.0422 \pm 0.0008^{\mathrm{E}}(57.8)$ & $0.1418 \pm 0.0015^{\mathrm{D}}(29.1)$ \\
\hline & & CSP60 & $<\mathrm{LOD}^{\mathrm{G}}$ & $0.0321 \pm 0.0026^{\mathrm{G}}(67.9)$ & $0.1058 \pm 0.0011^{\mathrm{G}}(47.1)$ \\
\hline & & CAC & $<\mathrm{LOD}^{\mathrm{G}}$ & $<\mathrm{LOD}^{\mathrm{J}}$ & $0.0308 \pm 0.0020^{\mathrm{MN}}(84.6)$ \\
\hline & & CBENT & $<\mathrm{LOD}^{\mathrm{G}}$ & $<\mathrm{LOD}^{\mathrm{J}}$ & $0.0225 \pm 0.0006^{\mathrm{p}}(88.8)$ \\
\hline & \multirow{4}{*}{$\begin{array}{l}\text { Acid } \\
\text { treated }\end{array}$} & $\mathrm{C}$ & $0.0191 \pm 0.0008^{\mathrm{F}}(61.8)$ & $0.0367 \pm 0.0017^{\mathrm{F}}(63.3)$ & $0.1332 \pm 0.0017^{\mathrm{E}}(33.4)$ \\
\hline & & CSP60 & $0.0280 \pm 0.0010^{\mathrm{C}}(44)$ & $0.0536 \pm 0.0017^{\mathrm{CD}}(46.4)$ & $0.1569 \pm 0.0019^{\mathrm{B}}(21.6)$ \\
\hline & & $\mathrm{CAC}$ & $<\mathrm{LOD}^{\mathrm{G}}$ & $<\mathrm{LOD}^{\mathrm{J}}$ & $0.0257 \pm 0.0014^{\mathrm{O}}(87.2)$ \\
\hline & & CBENT & $<\mathrm{LOD}^{\mathrm{G}}$ & $<\mathrm{LOD}^{\mathrm{J}}$ & $0.0266 \pm 0.0012^{\circ}(86.7)$ \\
\hline \multirow{8}{*}{$10^{9}$} & \multirow{4}{*}{ Heat killed } & $\mathrm{C}$ & $<\mathrm{LOD}^{\mathrm{G}}$ & $0.0263 \pm 0.0024^{\mathrm{H}}(73.7)$ & $0.0949 \pm 0.0023^{\mathrm{H}}(52.6)$ \\
\hline & & CSP60 & $<\mathrm{LOD}^{\mathrm{G}}$ & $0.0203 \pm 0.0010^{\mathrm{I}}(79.7)$ & $0.0822 \pm 0.0014^{\mathrm{J}}(58.9)$ \\
\hline & & $\mathrm{CAC}$ & $<\mathrm{LOD}^{\mathrm{G}}$ & $<\mathrm{LOD}^{\mathrm{J}}$ & $0.0209 \pm 0.0016^{\mathrm{P}}(89.6)$ \\
\hline & & CBENT & $<\mathrm{LOD}^{\mathrm{G}}$ & $<\mathrm{LOD}^{\mathrm{J}}$ & $<\mathrm{LOD}^{\mathrm{Q}}$ \\
\hline & \multirow{4}{*}{$\begin{array}{l}\text { Acid } \\
\text { treated }\end{array}$} & $\mathrm{C}$ & $<\mathrm{LOD}^{\mathrm{G}}$ & $0.0214 \pm 0.0010^{\mathrm{I}}(78.6)$ & $0.0855 \pm 0.0018^{\mathrm{I}}(57.3)$ \\
\hline & & CSP60 & $0.0201 \pm 0.0014^{\mathrm{F}}(59.8)$ & $0.0359 \pm 0.0022^{\mathrm{F}}(64.1)$ & $0.1108 \pm 0.0019^{\mathrm{F}}(44.6)$ \\
\hline & & $\mathrm{CAC}$ & $<\mathrm{LOD}^{\mathrm{G}}$ & $<\mathrm{LOD}^{\mathrm{J}}$ & $<\mathrm{LOD}^{\mathrm{Q}}$ \\
\hline & & CBENT & $<\mathrm{LOD}^{\mathrm{G}}$ & $<\mathrm{LOD}^{\mathrm{J}}$ & $<\mathrm{LOD}^{\mathrm{Q}}$ \\
\hline
\end{tabular}

${ }^{a} \mathrm{C}$ : Cells only, ${ }^{b} \mathrm{CSP} 60$ : Cells treated with sorbitan monostearate (Span 60), ${ }^{\mathrm{c}} \mathrm{CAC}$ : Cells in combination with activated carbon, ${ }^{\mathrm{d}}$ CBENT: Cells in combination with bentonite

Different capital letters within same column show significant difference $(\mathrm{p}<0.05)$

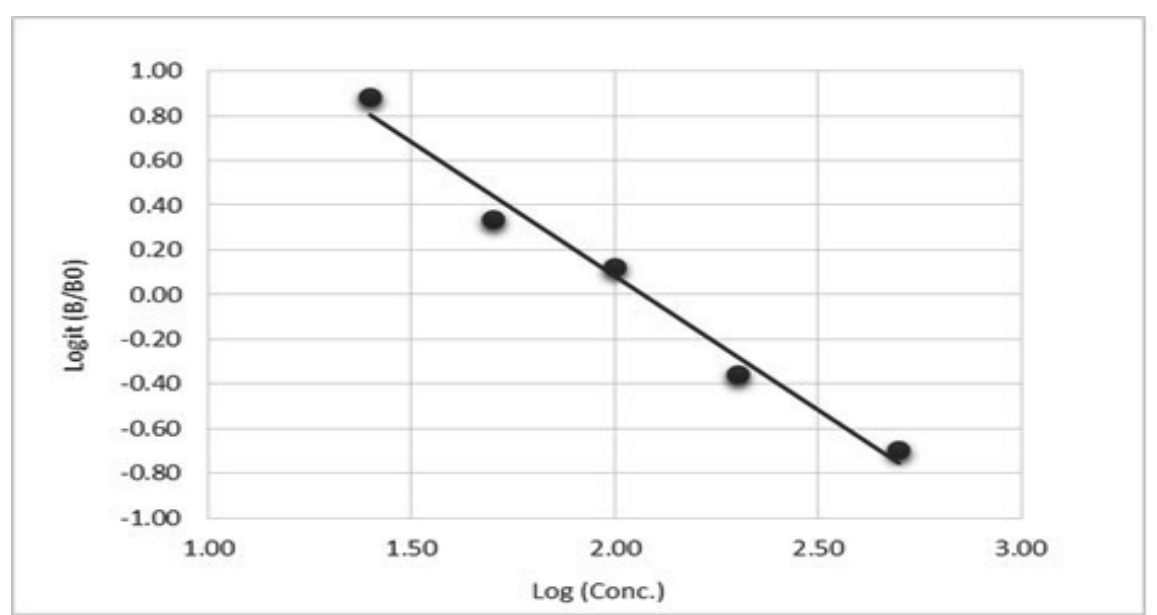

Figure. 1 Calibration curve of aflatoxin $M_{1}$. B/B0 represents absorbance at $450 \mathrm{~nm}$ for the sample, or the standard divided by absorbance at the same wavelength for the control.

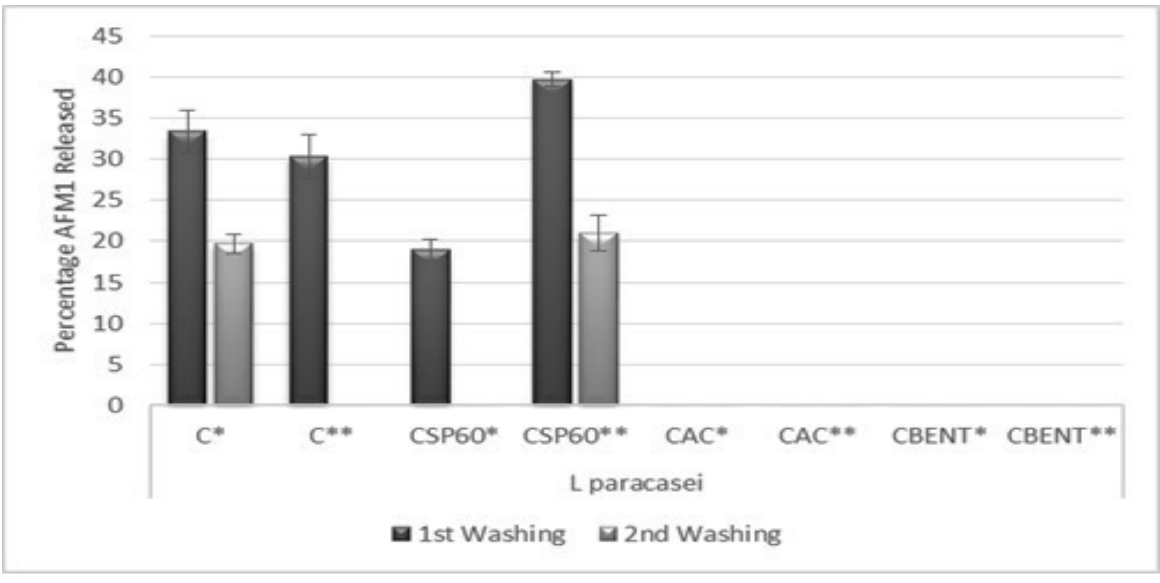




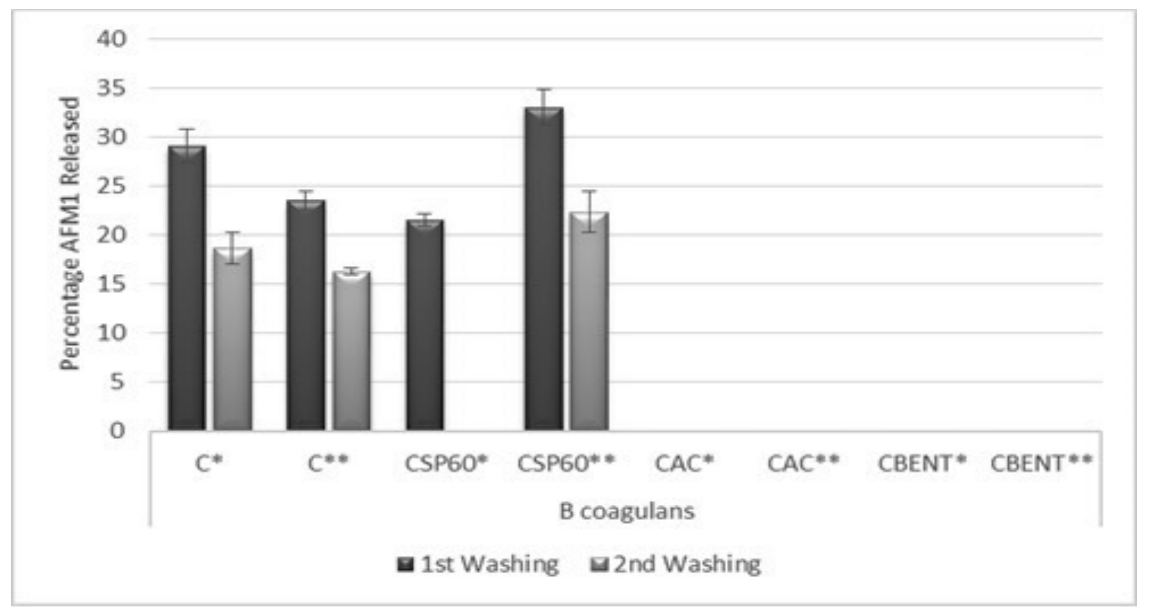

Figure. 2 Percentage of initially bound AFM 1 released after 2 washings with PBS for treatments involving (a) $L$. paracasei and (b) B. coagulans

C: Cells only, CSP0: Cells treated with sorbitan monostearate (Span 60), CAC: Cells in combination with activated carbon, CBENT: Cells in Combination with bentonite

${ }^{*}$ Treatments involving heat killed cells

** Treatments involving acid treated cell

\section{DISCUSSION}

The GRAS (Generally Recognized As Safe) status of LAB and probiotics along with their natural occurrence in variety of food commodities have encouraged the researchers to explore their $\mathrm{AFM}_{1}$ reducing potentials (Elsanhoty et al., 2014; Serrano-Niño et al., 2013). The removal of $\mathrm{AFM}_{1}$ through binding with bacterial cell wall involving non covalent interactions and subsequent removal by centrifugation has been reported to be an efficient method for its decontamination (Bovo et al., 2013; Serrano-Niño et al., 2013). The current study was also based upon utilization of two bacteria belonging to the said categories which had not been reported earlier for $\mathrm{AFM}_{1}$ decontamination. Furthermore, the novelty of this study was the application of the bacterial strains in combination with span 60 , activated carbon and bentonite for $\mathrm{AFM}_{1}$ reduction in milk. These combinations, to the best of our knowledge, have not been studied before for $\mathrm{AFM}_{1}$ decontamination in any media.

The results of the study showed a direct relation of bacterial cells concentration with amounts of $\mathrm{AFM}_{1}$ removed (Table 2 and 3). Higher bacterial cell concentrations were able to reduce $\mathrm{AFM}_{1}$ to a larger extent from milk samples spiked with $\mathrm{AFM}_{1}$. This clearly depicted that degree of $\mathrm{AFM}_{1}$ removal was dependent upon cell concentration as reported previously by Ismail et al. (2017) who showed reduction ranging between 73\% to $100 \%, 41 \%$ to $74 \%, 27 \%$ to $54 \%$ and $13 \%$ to $42 \%$ using $10^{10}, 10^{9}, 10^{8}$ and $10^{7} \mathrm{cfu} / \mathrm{ml}$ bacterial cells, respectively depending upon initial levels of $\mathrm{AFM}_{1}$ in milk. Kabak and Var (2008) also observed a decrease in $\mathrm{AFM}_{1}$ removal when the bacterial cell concentrations were reduced from $10^{8} \mathrm{cfu} / \mathrm{ml}$ to $10^{7} \mathrm{cfu} / \mathrm{ml}$ with $\mathrm{AFM}_{1}$ removal ranging between 10.22 to $26.65 \%$ and 0 to $5.02 \%$, respectively. Another study by El-Nezami et al. (1998a) suggested that cell concentrations of lactic acid bacteria in excess of $10^{9} \mathrm{cfu} / \mathrm{ml}$ were required for efficient removal of aflatoxins. Although the removal of $\mathrm{AFM}_{1}$ was in linear relation with cell concentration, the percentage reduction in $\mathrm{AFM}_{1}$ decreased when the initial $\mathrm{AFM}_{1}$ levels were increased beyond a certain point among similar cell concentrations. The study by Ismail et al. (2017) also revealed if bacterial cell concentration was kept constant, the percentage of $\mathrm{AFM}_{1}$ removal decreased when initial $\mathrm{AFM}_{1}$ levels were increased. Line and Brackett (1995) proposed a similar trend showing decrease in percentage decontamination after the milk was spiked with aflatoxins beyond a certain limit. This indicated that there were limited binding sites on bacterial cell walls at which $\mathrm{AFM}_{1}$ could form a complex. As the cell concentrations increased, the amount of available binding sites also increased, but as the $\mathrm{AFM}_{1}$ concentration was increased, the percentage removal started to decrease when the binding assay reached a saturation point. Although Kabak and Var (2008) showed no effect of $\mathrm{AFM}_{1}$ concentration on the percent removal efficiencies of bacterial cells showing 23.48\%, 26.62\% and $24.77 \% \mathrm{AFM}_{1}$ removal at 5,10 and $20 \mu \mathrm{g} / \mathrm{L}$, respectively but the amounts of $\mathrm{AFM}_{1}$ removed increased with increase in $\mathrm{AFM}_{1}$ concentration which might have occurred due to lack in satisfaction of bacterial cell binding sites at lower concentrations of spiking with $\mathrm{AFM}_{1}$.

Since many of the previous studies have ruled out the role of metabolic degradation of aflatoxins through bacterial cells on the basis of higher binding efficiencies by nonviable cells as compared to those 
shown by viable cells (Bovo et al., 2013; Corassin et al., 2013; El-Nezami et al., 1998a, b; Elsanhoty et al., 2014; Pierides et al., 2000), heat killed and acid treated cells were utilized for $\mathrm{AFM}_{1}$ removal in the current study. Furthermore, their usage might also not result in any undesirable fermentative changes in milk that could have been caused by in case of viable cells. Due to the capability of nonviable cells to remove aflatoxins, it had been suggested that components of bacterial cell wall, including peptidoglycans and polysaccharides, were majorly involved in toxin removal through formation of a non-covalent complex with aflatoxins (Lahtinen et al., 2004; Shetty et al., 2007). The acid and heat treatments may have drastic effect on bacterial cell wall peptidoglycans and polysaccharides. The heat treatment may cause denaturation of cell wall proteins resulting changes in interactions or may form maillard reaction products as well. Likewise, acid treatment may affect the cell wall by breaking the glycosidic linkages between polysaccharides causing formation of monomers which may convert into aldehydes or by hydrolysis of proteins into smaller peptides and amino acids. Furthermore, the acid treatment may compromise the structural integrity of cell wall by breaking the peptidoglycan, consequently reducing the thickness of this layer and increasing the pore size by decreasing cross linkages (Haskard et al., 2001). These changes might expose the sites of microbial cell which were previously unavailable towards binding with aflatoxins (El-Nezami et al., 1998b; Haskard et al., 2000). The $A_{F} M_{1}$ reduction patterns of acid and heat treatments of $\mathrm{C}$ for both the strains tested in this study were in contrast from each other. The acid treated $\mathrm{C}$ of $B$. coagulans had higher binding efficiencies than heat killed C. In contrast, L. Paracasei showed less removal of $\mathrm{AFM}_{1}$ through acid treated $\mathrm{C}$ in comparison to heat killed C. This might have occurred due to differences in cell wall structures of both the bacteria resulting in varying exposures of binding sites as a result of $\mathrm{HCl}$ treatment. Furthermore, the study revealed various binding capacities for both the strains tested. The binding properties might have been different due to varying degree of changes among the structure and the composition of cell wall (Piuri et al., 2005; Vinderola et al., 2000).

Haskard et al. (2000) suggested that the protein denaturation due to acid and heat treatment results in formation of hydrophobic surfaces which further act as binding sites for aflatoxins. In an attempt to increase the binding sites of bacterial cell wall, the cells were treated with sorbitan monostearate (Span 60). Sorbitan monostearate (SP60) has low Hydrophile-Lipophile Balance (HLB) value and is used for water in oil emulsions (Gadhave, 2014). Furthermore, SP60 is used as an emulsifier in various food commodities (E 491). The ADI for sorbitan esters either alone or in combination is $10 \mathrm{mg} / \mathrm{kg}$ body weight per day and the SP60 has been shown to have no observed adverse effect level (NOAEL) up to $2,600 \mathrm{mg} / \mathrm{kg}$ body weight per day (EFSA, 2017). The results of our study showed higher levels of decontamination through acid and heat killed CSP60 of L. paracasei in comparison to its $\mathrm{C}$ counterparts. This might have happened due to binding of SP60 with relatively higher hydrophobic sites of bacterial cell wall which were previously vacant as $\mathrm{AFM}_{1}$ could not bind at these sites due to large differences in polarity. This phenomenon might have further exposed the relatively less hydrophobic regions of sorbitan monostearate to form a complex with $\mathrm{AFM}_{1}$, consequently increasing the binding efficiency of the cells. For B. coagulans, higher levels of $\mathrm{AFM}_{1}$ removal were achieved for heat killed CSP60 than heat killed C treatment, while lower levels of $\mathrm{AFM}_{1}$ removal were achieved in case of acid treated CSP60 as compared to acid treated $\mathrm{C}$ treatment. This can be explained in light of varying structure and composition of cell wall resulting in different effect of acid treatment on different bacteria (Piuri et al., 2005; Vinderola et al., 2000). The heat treatment might have exposed larger number of relatively higher hydrophobic sites favoring the binding of $\mathrm{AFM}_{1}$ through SP60 complex, while the acid treatment may have exposed more binding sites favoring formation of $\mathrm{AFM}_{1}$ complex directly with bacterial cell wall.

Number of studies have shown the aflatoxin removal capacities for bentonite and activated carbon by addition in animal diet (Diaz et al., 2004; Jaynes et al., 2007), however the direct exposure of milk with these adsorbents for $\mathrm{AFM}_{1}$ removal have been studied in very few cases (Applebaum \& Marth, 1982). Although bentonite and activated carbon showed high $\mathrm{AFM}_{1}$ removal efficiencies in milk during previous studies but they also showed some changes in milk properties (Carraro et al., 2014; Di Natale et al., 2009). This study utilized less amounts of adsorbents (2\%) as compared to up to $5 \%$ of activated carbon and bentonite by Di Natale et al. (2009) and up to $10 \%$ bentonite by Carraro et al. (2014), additionally, the adsorbents were analyzed in combination with bacterial cells. The combination of cells with activated carbon and bentonite (CAC and CBENT) showed significantly higher removal of aflatoxins as compared to other treatments which might have been due to availability of more binding sites in the presence of both the bacterial cells and the adsorbent. In addition, higher affinities of these treatments towards $\mathrm{AFM}_{1}$ can be attributed to larger surface area and highly porous structure of activated carbon and bentonite (Di Natale et al. 2009). Furthermore, as the aflatoxins are mainly present in milk serum and casein (Ottaviani, 1991) and the milk serum mainly constitutes of water, the $\mathrm{AFM}_{1}$ hydrophobicity can promote its binding to surface of carbon which has more affinity towards $\mathrm{AFM}_{1}$. Similarly, formation of hydrogen bonding among aflatoxins molecules and bentonite edges might have 
resulted in efficient removal of $\mathrm{AFM}_{1}$ from spiked milk samples (Desheng et al., 2005). The variations among $\mathrm{AFM}_{1}$ binding abilities of these two agents can be due to variations in pore size and in chemical affinities between the surface functional groups of the adsorbent and toxin (Alfarra et al., 2004). Among the treatments involving activated carbon and bentonite, the bentonite treatment was found to be more effective as compared to activated carbon. These results were in contrast to the studies of Di Natale et al. (2009) who showed higher $\mathrm{AFM}_{1}$ binding ability of activated carbon as compared to bentonite. However, this variation can be attributed to the presence of microbial cells in the medium which could have adsorbed on the activated carbons consequently decreasing the porosity and $\mathrm{AFM}_{1}$ adsorption (Rivera et al., 2001). In addition, the simultaneous presence of bacterial cells and bentonite in a medium may result in formation of bacteria-bentonite clusters which may trap the $\mathrm{AFM}_{1}$ increasing the efficiency of the treatment (Yang et al., 2012).

The complex of CAC and CBENT with $\mathrm{AFM}_{1}$ for both heat and acid treatments was found to be most stable followed by heat killed CSP60. The results were almost in line with the study of Ismail et al. (2017), who showed release of $19.5 \%$ to $69.8 \%$ of initially bound $\mathrm{AFM}_{1}$ by various lactobacillus strains and their mixture. Bovo et al. (2013) reported the release of $40.57 \%$ to $87.37 \%$ of initially bound $\mathrm{AFM}_{1}$ by lactobacillus strains after washings with PBS solution. The presence of weak non covalent hydrophobic interactions between microbial cells and $\mathrm{AFM}_{1}$ were suggested to be the cause of low $\mathrm{AFM}_{1}$ retention by microbial cells (Serrano-Niño et al. 2013). In contrast, Kabak and Var (2008) revealed the release of only $5.62-8.54 \%$ of bound $\mathrm{AFM}_{1}$ by using various Lactobacillus and Bifidobacterium strains. The variations among different strains treated with heat and acid in addition to SP60 can be attributed to differences in binding sites of various strains as a result of denaturation or hydrolysis of cell wall components. Lower levels of release for $\mathrm{AFM}_{1}$ might have been due to interactions among $\mathrm{AFM}_{1}$ molecules with cell walls of adjacent bacterium, consequently developing a crosslinked matrix to prevent aflatoxin release due to washings with PBS (Hernandez-Mendoza et al., 2009). Although, higher stability levels were achieved in our study, but there is still a need to study in detail the exact mechanism for release of $\mathrm{AFM}_{1}$ bound to microbial cells under various conditions in order to decrease their release in different environments.

The two bacterial cells $L$. paracase $i$ and $B$. coagulans were found to be effective at higher concentrations in reducing $\mathrm{AFM}_{1}$ levels. Furthermore, the combinations of bacterial cells with activated carbon and bentonite proved to be more efficient as the removal of up to $100 \% \mathrm{AFM}_{1}$ was achieved. Moreover, microbial cell-AFM $\mathrm{Al}_{1}$ complex in the presence of these combinations proved to be more stable as compared to cells alone. The addition of sorbitan monostearate also increased the binding capacity of heat killed and acid treated $L$. paracasei cells and heat treated B. coagulans cells. The stability of microbial cell- $\mathrm{AFM}_{1}$ complex due to treatment with SP60 was also enhanced but it was less than that achieved by addition of bentonite and activated carbon. In addition, treatment of cells with SP60 also resulted in higher $\mathrm{AFM}_{1}$ removal efficiency which can be attributed to exposure of new binding sites due to role of SP60 as a bridge between highly hydrophobic sites of cell wall and hydrophilic $\mathrm{AFM}_{1}$. The utilization of the adsorbents analyzed in this study in combination with microbial cells can prove to be highly efficient in terms of reducing $\mathrm{AFM}_{1}$ to below permissible limits and its daily intake among humans without posing any probable side effects. Hence, the addition of an operation such as filtration using composite materials based on agents used in the study for milk processing can be explored further. Although, this might add another processing step, but the milk having $\mathrm{AFM}_{1}$ above maximum limits can be utilized for dairy products, if not for direct consumption, after processing instead of being wasted. Nevertheless, future studies must be focused on the effect of these materials on the properties of milk and further optimization of the process.

Acknowledgement: The authors are very thankful for Higher Education Commission, Pakistan to support the study under 5000 Indigenous $\mathrm{PhD}$ fellowship program. This work is the part of $\mathrm{PhD}$ studies of Mr. Khurram Muaz under the supervision of Dr. Muhammad Riaz at Institute of Food Science and Nutrition, Bahauddin Zakariya University Multan-Pakistan.

Conflicts of interest: None.

\section{REFERENCES}

Alfarra, A., E. Frackowiak, and F. Béguin (2004). The HSAB concept as a means to interpret the adsorption of metal ions onto activated carbons. Appl. Surf. Sci. 228(1-4):84-92. https://doi.org/ 10.1016/j.apsusc. 2003.12.033

Applebaum, R. S., and E. H. Marth (1982). Use of sulphite or bentonite to eliminate aflatoxin $\mathrm{M}_{1}$ from naturally contaminated raw whole milk. Zeitschrift für Lebensmittel-Untersuchung und Forschung, 174(4):303-305.

Bovo, F., C. H. Corassin, R. E. Rosim, and C. A. de Oliveira (2013). Efficiency of lactic acid bacteria strains for decontamination of aflatoxin $\mathrm{M}_{1}$ in phosphate buffer saline solution and in skimmed milk. Food Bioprocess. Tech. 6(8):2230-2234. http://doi.org/10.1007/s11947-011-0770-9

Carraro, A., A. De Giacomo, M. L. Giannossi, L. Medici, M. Muscarella, L. Palazzo, V. Quaranta, V. 
Summa, and F. Tateo (2014). Clay minerals as adsorbents of aflatoxin $\mathrm{M}_{1}$ from contaminated milk and effects on milk quality. Applied Clay Sci. https://doi.org/10.1016/j.clay.2013.11.028

Corassin, C., F. Bovo, R. Rosim, and C. Oliveira (2013). Efficiency of Saccharomyces cerevisiae and lactic acid bacteria strains to bind aflatoxin $M 1$ in UHT skim milk. Food Control. 31(1):80-83. https://doi.org/10.1016/j.foodcont.2012.09.033

Cotty, P. J., and K. F. Cardwell (1999). Divergence of West African and North American Communities of Aspergillus SectionFlavi. Appl. Environ. Microbiol. 65(5):2264-2266.

Desheng, Q., L. Fan, Y. Yanhu, and Z. Niya (2005). Adsorption of aflatoxin $\mathrm{B}_{1}$ on montmorillonite. Poult. Sci. 84(6):959-961. https://doi.org/10.1093/ps/84.6.959

Di Natale, F., M. Gallo, and R. Nigro (2009). Adsorbents selection for aflatoxins removal in bovine milks. J. Food Eng. 95(1):186-191. https://doi.org/10.1016/j.jfoodeng.2009.04.023

Diaz, D. E., W. M. Hagler, J. T. Blackwelder, J. A. Eve, B. A. Hopkins, K. L. Anderson, F. T. Jones, and L. W. Whitlow (2004). Aflatoxin binders II: Reduction of aflatoxin $\mathrm{M}_{1}$ in milk by sequestering agents of cows consuming aflatoxin in feed. Mycopathologia. 157(2):233-241.

EFSA Panel on Food Additives and Nutrient Sources added to Food (ANS), et al. "Re-evaluation of sorbitan monostearate (E 491), sorbitan tristearate (E 492), sorbitan monolaurate (E 493), sorbitan monooleate (E 494) and sorbitan monopalmitate (E 495) when used as food additives." EFSA J. 15.5 (2017): e04788.

El-Nezami, H., P. Kankaanpaa, S. Salminen, and J. Ahokas (1998a). Ability of dairy strains of lactic acid bacteria to bind a common food carcinogen, aflatoxin $\mathrm{B}_{1}$. Food Chem .Toxicol. 36(4):321$326 . \quad \mathrm{https} / /$ doi.org/10.1016/S02786915(97)00160-9

El-Nezami, H., P. Kankaanpaa, S. Salminen, and J. Ahokas (1998b). Physicochemical alterations enhance the ability of dairy strains of lactic acid bacteria to remove aflatoxin from contaminated media. J. Food Prot. 61(4):466-468. https://doi.org/10.4315/0362-028X-61.4.466

Elsanhoty, R. M., S. A. Salam, M. F. Ramadan, and F. H. Badr (2014). Detoxification of aflatoxin $M_{1}$ in yoghurt using probiotics and lactic acid bacteria. Food Control. 43:129-134. https://doi.org/ 10.1016/j.foodcont.2014.03.002

Endres, J., A. Clewell, K. Jade, T. Farber, J. Hauswirth, and A. Schauss. (2009). Safety assessment of a proprietary preparation of a novel Probiotic, Bacillus coagulans, as a food ingredient. Food
Chem Toxicol. 47(6): 1231-1238. https://doi.org/10.1016/j.fct.2009.02.018

Fallah, A. A. (2010). Aflatoxin $\mathrm{M}_{1}$ contamination in dairy products marketed in Iran during winter and summer. Food Control. 21(11):1478-1481. https://doi.org/10.1016/j.foodcont.2010.04.017

Fallah, A. A., M. Rahnama, T. Jafari, and S. S. SaeiDehkordi (2011). Seasonal variation of aflatoxin $\mathrm{M}_{1}$ contamination in industrial and traditional Iranian dairy products. Food Control. 22(10):1653-1656. https://doi.org/10.1016/j.foodcont.2011.03.024

FDA (2018). Bentonite. 21CFR184.1155, Code of Federal Regulations, Title 21, Volume 3. https:/www.accessdata.fda.gov/scripts/cdrh/cfdo cs/cfcfr/CFRSearch.cfm?fr=184.1155\&SearchTer $\mathrm{m}=$ bentonite. Accessed 12 August 2019.

Gadhave, A. (2014). Determination of hydrophiliclipophilic balance value. Int. J. Sci. Res. 3(4):573575.

Haskard, C., C. Binnion, and J. Ahokas (2000). Factors affecting the sequestration of aflatoxin by Lactobacillus rhamnosus strain GG. Chem. Biol. Interact. 128(1):39-49. https://doi.org/10.1016/ S0009-2797(00)00186-1

Haskard, C. A., H. S. El-Nezami, P. E. Kankaanpää, S. Salminen, and J. T. Ahokas (2001). Surface binding of aflatoxin $\mathrm{B}_{1}$ by lactic acid bacteria. Appl. Environ. Microbiol. 67(7):3086-3091. https://doi.org/10.1128/AEM.67.7.30863091.2001

Hernandez-Mendoza, A., D. Guzman-de-Peña, and H. Garcia (2009). Key role of teichoic acids on aflatoxin $\mathrm{B}_{1}$ binding by probiotic bacteria. $\mathrm{J}$. Appl. Microbiol. 107(2):395-403. https://doi.org/10.1111/j.1365-2672.2009.04217.x

Ismail, A., M. Riaz, R. E. Levin, S. Akhtar, Y. Y. Gong, and A. Hameed, (2016). Seasonal prevalence level of aflatoxin M1 and its estimated daily intake in Pakistan. Food Control. 60: 461-465. https://doi.org/10.1016/j.foodcont.2015.08.025

Ismail, A., R. E. Levin, M. Riaz, S. Akhtar, Y. Y. Gong, and C. A. de Oliveira (2017). Effect of different microbial concentrations on binding of aflatoxin $\mathrm{M}_{1}$ and stability testing. Food Control. 73:492496. https://doi.org/10.1016/j.foodcont.2016.08.040

Jaynes, W., R. Zartman, and W. Hudnall (2007). Aflatoxin B1 adsorption by clays from water and corn meal. Appl. C; ay Sci. 36: 197-205 https://doi.org/10.1016/j.clay.2006.06.012

Jia, X., W. Wang, Y. Song, and N. Li. (2011). A 90-day oral toxicity study on a new strain of Lactobacillus paracasei in rats. Food Chem Toxicol. 49(5): 1148-1151. https://doi.org/ 10.1016/j.fct.2011.02.006 
Kabak, B., and I. Var (2008). Factors affecting the removal of aflatoxin M1 from food model by Lactobacillus and Bifidobacterium strains. J. Environ. Sci. Health Part B. 43(7):617-624. https://doi.org/10.1080/03601230802234740

Kurtzman, C., B. Horn, and C. Hesseltine (1987). Aspergillus nomius, a new aflatoxin-producing species related to Aspergillus flavus and Aspergillus tamarii. Antonie Van Leeuwenhoek. 53(3):147-158.

Lahtinen, S., C. Haskard, A. Ouwehand, S. Salminen, and J. Ahokas (2004). Binding of aflatoxin $B_{1}$ to cell wall components of Lactobacillus rhamnosus strain GG. Food Addit. Contam. 21(2):158-164. https://doi.org/10.1080/02652030310001639521

Line, J., \& R. Brackett (1995). Factors affecting aflatoxin $\mathrm{B}_{1}$ removal by Flavobacterium aurantiacum. J. Food Prot. 58(1):91-94. https://doi.org/10.4315/0362-028X-58.1.91

Maqbool, U., Anwar-Ul-Haq, and M. Ahmad (2009). ELISA determination of Aflatoxin $\mathrm{M}_{1}$ in milk and dairy products in Pakistan. Toxicol. Environ. Chem. 91(2):241-249. https://doi.org/10.1080/02772240802144562

Mishra, H., and C. Das (2003). A review on biological control and metabolism of aflatoxin. Crit. Rev. Food Sci. Nutr. 43(3): 245-264. https://doi.org/10.1080/10408690390826518

Munir, M. A., M. Saleem, Z. Malik, M. Ahmed, and A. Ali (1989). Incidence of aflatoxin contamination in non-perishable food commodities. J. Pakistan Med. Assoc. 39(6):154-157.

Neal, G., D. Eaton, D. Judah, and A. Verma (1998). Metabolism and Toxicity of Aflatoxins $\mathrm{M}_{1}$ and $\mathrm{B}_{1}$ in Human-Derivedin Vitro Systems. Toxicol. Appl. Pharmacol. 151(1):152-158. https://doi.org/10.1006/taap.1998.8440

Ottaviani, F. (1991). L'analisi microbiologica dei prodotti lattiero-caseari: manuale di tecniche di laboratorio ed ecologia microbica. Tecniche nuove.

Peltonen, K. D., H. S. El-Nezami, S. J. Salminen, and J. T. Ahokas, (2000). Binding of aflatoxin $\mathrm{B}_{1}$ by probiotic bacteria. J. Sci. Food Agric. 80(13):1942-1945. https://doi.org/10.1002/10970010(200010)80:13\%3C1942::AID-

JSFA741\%3E3.0.CO;2-7

Peterson, S. W., Y. Ito, B. W. Horn, and T. Goto (2001). Aspergillus bombycis, a new aflatoxigenic species and genetic variation in its sibling species, $A$. nomius. Mycologia, 689-703.

Phillips, M., K. Kailasapathy, and L. Tran. (2006). Viability of commercial probiotic cultures (L. acidophilus, Bifidobacterium sp., L. casei, L. paracasei and L. rhamnosus) in cheddar cheese.
Int. J. Food Microbiol. 108(2): 276-280. https://doi.org/10.1016/j.ijfoodmicro.2005.12.009

Pierides, M., H. El-Nezami, K. Peltonen, S. Salminen, and J. Ahokas (2000). Ability of dairy strains of lactic acid bacteria to bind aflatoxin $M_{1}$ in a food model. J. Food Prot. 63(5):645-650. https://doi.org/10.4315/0362-028X-63.5.645

Piuri, M., C. Sanchez-Rivas, and S. Ruzal (2005). Cell wall modifications during osmotic stress in Lactobacillus casei. J. Appl. Microbiol. 98(1):8495. 2672.2004.02428.x

Rivera-Utrilla, J., I. Bautista-Toledo, M. A. Ferro-García, and C. Moreno-Castilla. (2001). Activated carbon surface modifications by adsorption of bacteria and their effect on aqueous lead adsorption. J. Chem. Technol. Biotechnol. 76(12): 1209-1215. https://doi.org/10.1002/jctb.506

Serrano-Niño, J. C., A. Cavazos-Garduño, A. HernandezMendoza, B. Applegate, M. G. Ferruzzi, M. F. San Martin-González, and H. S. García (2013). Assessment of probiotic strains ability to reduce the bioaccessibility of aflatoxin $\mathrm{M}_{1}$ in artificially contaminated milk using an in vitro digestive model. Food Control. 31(1):202-207. doi: https://doi.org/10.1016/j.foodcont.2012.09.023

Shetty, P. H., B. Hald, and L. Jespersen (2007). Surface binding of aflatoxin $\mathrm{B}_{1}$ by Saccharomyces cerevisiae strains with potential decontaminating abilities in indigenous fermented foods. Int. J. Food Microbiol. 113(1):41-46. https://doi.org/10.1016/j.ijfoodmicro.2006.07.013

Shibahara, T., H. I. Ogawa, H. Ryo, and K. Fujikawa (1995). DNA-damaging potency and genotoxicity of aflation $\mathrm{M}_{1}$ in somatic cells in vivo of Drosophila melanogaster. Mutagenesis. 10(3):161-164.

Vinderola, C. G., N. Bailo, and J. A. Reinheimer (2000). Survival of probiotic microflora in Argentinian yoghurts during refrigerated storage. Food Res. Int. 33(2):97-102. https://doi.org/10.1016/S09639969(00)00011-9

Wang, J. S., H. Luo, M. Billam, Z. Wang, H. Guan, L. Tang, T. Goldston, E. Afriyie-Gyawu, C. Lovett, J. Griswold, and B. Brattin (2005). Short-term safety evaluation of processed calcium montmorillonite clay (NovaSil) in humans. Food Addit. Contam. 22(3):270-279. https://doi.org/10.1080/02652030500111129

Yang, H., M. Tong, and H. Kim. (2012). Influence of bentonite particles on representative gram negative and gram positive bacterial deposition in porous media. Environ. Sci. Technol. 46(21): 11627-11634. https://doi.org/10.1021/es301406q. 